\title{
Penguasaan Semasa E-Kemahiran dalam Kalangan Pelajar UUM: Cabaran Dalam Era IR4.0
}

\author{
Present Mastery of E-Skill Among UUM Students: \\ Challenges in IR4.0 Era \\ Wan Hussain Wan Ishak ${ }^{* a} \&$ Fadhilah Mat Yamin ${ }^{\mathrm{b}}$ \\ ${ }^{a}$ Pusat Pengajian Pengkomputeran, Universiti Utara Malaysia, \\ Sintok, Kedah, Malaysia \\ ${ }^{b}$ Pusat Pengajian Pengurusan Teknologi dan Logistik, \\ Universiti Utara Malaysia, Sintok, Kedah, Malaysia
}

Received: 30/1/2020 Revised: 26/5/2020 Accepted: 3/6/2020 Published: 30/6/2020

\begin{abstract}
Abstrak
E-kemahiran merupakan salah satu aset penting yang perlu ada pada setiap graduan yang bakal memasuki dunia pekerjaan. Ini seiring dengan cabaran dan keperluan bagi mengguna pakai teknologi terkini dalam pengurusan dan operasi di industri akibat daripada letusan revolusi industri 4.0 (IR4.0). Ini kerana IR4.0 memerlukan tenaga kerja berpengetahuan dan berkemahiran sebagai penggerak utamanya. Kertas kerja ini membincangkan kajian kes penguasaan e-kemahiran yang telah dijalankan ke atas sekumpulan pelajar tahun akhir di Universiti Utara Malaysia. Dapatan kajian menunjukkan pelajar amat sedar akan kepentingan teknologi maklumat dan komunikasi (ICT) dalam pembelajaran dan kerjaya mereka. Walau bagaimanapun, ujian praktikal yang dijalankan menunjukkan tahap penguasaan ICT pelajar masih di peringkat sederhana. Justeru, pelajar perlu mengenal pasti kelemahan mereka dan meningkatkan kemahiran sebelum memasuki pasaran kerja.
\end{abstract}

Katakunci: Teknologi Maklumat dan Komunikasi (ICT), E-Kemahiran, Kemahiran ICT, Revolusi Industri 4.0

Abstract

E-skills are one of the important assets that every graduate should have before joining the working place. This is in line with the challenges and needs of adopting the latest technology in management and operations in the industry as a result of the industrial revolution 4.0 (IR4.0). This is because IR4.0 requires a knowledgeable and skilled

* Corresponding Author Email: hussain@uum.edu.my 
workforce as its main driver. This paper discusses a case study of e-skills mastery conducted on a group of final year students at Universiti Utara Malaysia. The findings show that students are aware of the importance of information and communication technology (ICT) in their learning and careers. However, practical tests conducted show that students' level of ICT is still at a moderate level. Therefore, students need to identify their weaknesses and improve their skills before entering the job market.

Keywords: Information and Communication Technology (ICT), E-Skill, ICT Skills, Industrial Revolution 4.0

\subsection{Pengenalan}

E-kemahiran atau kemahiran menggunakan teknologi maklumat dan komunikasi (ICT) merupakan suatu kemestian bagi graduan. Ini kerana, ICT bukan sahaja digunakan dalam urusan sosial tetapi juga sebagai alatan penting dalam pengurusan dan operasi sesebuah organisasi. Malah, ICT merupakan alatan terpenting yang mendukung perkembangan industri dan kemajuan ekonomi sesebuah negara (Toader et al., 2018).

Secara umumnya e-kemahiran didefinisikan sebagai kemahiran atau penguasaan pengetahuan berkaitan dengan ICT (Lanvin \& Kralik, 2009). Kemahiran berkaitan ICT adalah keupayaan untuk menggunakan ICT untuk pelbagai tujuan termasuk peribadi, sosial dan perniagaan. E-kemahiran boleh dibahagikan kepada tiga kategori: kemahiran pengguna ICT, kemahiran pengamal ICT, dan kemahiran e-kepimpinan (Gareis et al., 2014). Kemahiran pengamal ICT adalah keupayaan penggunaan kemahiran ICT untuk pelbagai tugas seperti penyelesaian masalah, pemasaran, pentadbiran dan perancangan. Kemahiran pengguna ICT adalah keupayaan yang berkaitan dengan penggunaan aplikasi, sistem, alat dan peranti ICT oleh individu. Sementara itu, kemahiran e-kepimpinan merujuk kepada keupayaan yang dimiliki oleh pemimpin organisasi untuk mencapai matlamat organisasi.

Kemunculan Revolusi Industri 4.0 (IR4.0) membuktikan bahawa ICT merupakan teras utama bagi pembangunan industri di zaman ini. Malah, kebergantungan terhadap ICT makin utuh apabila hampir semua aplikasi yang dimajukan dalam IR4.0 memfokus kepada automasi berkomputer. Secara umum, IR4.0 mendukung sebelas teknologi termaju iaitu Big Data, Artificial Intelligence, Augmented Reality, Additive Manufacturing, Cybersecurity, Simulation, Advanced Materials, System Integration, Autonomous Robots, Internet of Things dan Cloud Computing (MITI, 2018). Perkembangan ini turut memberi cabaran baharu kepada negara dalam mencapai status negara maju dan berteknologi tinggi.

Justeru, pemain industri perlu meningkatkan penggunaan alatan ICT termaju dalam operasi mereka. Industri yang berjaya mengadaptasikan IR4.0 dalam operasi mereka 
akan menikmati pelbagai kelebihan seperti; pengurangan kos, peningkatan kecekapan organisasi, kecekapan dalam membuat keputusan dan meningkatkan daya saing organisasi (Linton, 2018; Palvalin et al., 2013). Sebaliknya, kelemahan penguasaan ICT dalam organisasi akan mengurangkan keberkesanan penggunaan ICT (Plaatjies \& Mitrovic, 2014) dan melemahkan daya saing organisasi. Bagi mencapai matlamat ini, pihak industri memerlukan kakitangan yang mampu mengaplikasikan dan mengendalikan alatan ICT seiring dengan keperluan dan kehendak semasa industri.

Selaras dengan keperluan IR4.0, kebolehan menggunakan teknologi ICT secara berkesan dilihat sebagai prasyarat untuk memasuki pasaran kerja pada hari ini. Oleh itu, bagi memenuhi keperluan industri, pelajar yang bakal menyertai industri perlu mempunyai kemahiran ICT yang mencukupi. Pelajar yang mempunyai kemahiran ICT yang mencukupi dijangka akan mampu menggunakan pelbagai sumber yang ada seperti perkakasan komputer, rangkaian komputer, perisian dan Internet bagi memenuhi keperluan maklumat dan menyelesaikan masalah di organisasi.

Di universiti, pelajar telah didedahkan dengan penggunaan ICT yang cekap dalam pembelajaran mereka. Sebagai contoh, melalui perkakasan, alatan dan perisian yang ada, pelajar boleh mencari pelbagai maklumat, menapis dan membuat analisis yang diperlukan dengan cepat (Yamin \& Ishak, 2016). Penyelidikan terdahulu juga menunjukkan bahawa penggunaan ICT membawa kepada prestasi akademik yang lebih baik (Hoskins \& van Hooff, 2005; Ishak et al., 2015; Hernandez, 2017; Basri et al., 2018). Pencapaian ini secara tidak langsung akan meningkatkan merit pelajar dalam proses pencarian pekerjaan. Pelajar yang lemah kemahiran ICT akan ketinggalan dan tidak akan mampu bersaing dalam pasaran kerja (Tyler, 2005).

Dalam kajian ini, fokus kajian adalah terhadap kemahiran yang berkaitan dengan penggunaan peranti ICT, alatan dan aplikasi teknologi maklumat (IT) oleh pelajar sarjana muda. Oleh itu, e-kemahiran juga dirujuk sebagai kemahiran ICT atau kemahiran IT. Sebagai kajian kes, pelajar tahun akhir dipilih secara rawak sebagai responden kajian. Kajian dilakukan secara praktikal dalam makmal komputer dan dibantu oleh fasilitator terlatih.

\subsection{Perkembangan ICT di Malaysia}

Wawasan 2020 yang telah diperkenalkan pada tahun 1991 telah memandu Malaysia bagi mencapai kemajuan dalam pelbagai bidang terutama perindustrian. Selari dengan wawasan tersebut, Malaysia pada hari ini telah mencapai banyak kejayaan dari pelbagai aspek pengurusan dan penggunaan teknologi seperti ICT. Penubuhan Koridor Raya Multimedia (MSC) pada tahun 1996, merupakan pemacu utama terhadap perkembangan ICT di Malaysia. Melaluinya, masyarakat disedarkan akan keperluan dan kepentingan ICT dalam pelbagai urusan seperti sosial, pengurusan dan perniagaan. 
Tujuh aplikasi perdana MSC iaitu kerajaan elektronik, tele-perubatan, sekolah pintar, kad pelbagai guna, kluster pembangunan dan penyelidikan, rangkaian pengeluaran sedunia, dan pemasaran tanpa sempadan telah memberi tujahan baharu terhadap amalan semasa dalam pengurusan, pentadbiran dan operasi terutama dalam sektor industri dan kerajaan. Secara langsung, MSC memberi kesan positif ke atas ekonomi Malaysia (Ramlan \& Ahmed, 2010).

MSC juga telah menukar keperluan dan gaya hidup masyarakat Malaysia. Pada masa kini, ICT telah dikenali dan digunakan dengan meluas oleh setiap lapisan masyarakat dan industri. Suruhanjaya Komunikasi dan Multimedia Malaysia (SKMM) telah melaporkan purata penggunaan dan capaian ICT oleh individu dan isi rumah di Malaysia pada tahun 2018 adalah sebanyak 71.7\% (SKMM, 2018a). Rajah 1 menunjukkan statistik penggunaan peranti komputer di Malaysia sehingga bulan Februari tahun 2015. Telefon pintar dan telefon mudah alih merupakan antara peranti yang paling popular. Peranti ini merupakan alat komunikasi terpenting di abad ini. Ianya juga mudah digunakan dan mudah dibawa. Di samping itu, penggunaan ini juga didorong oleh perkembangan capaian Internet yang kini boleh dicapai melalui telefon pintar.

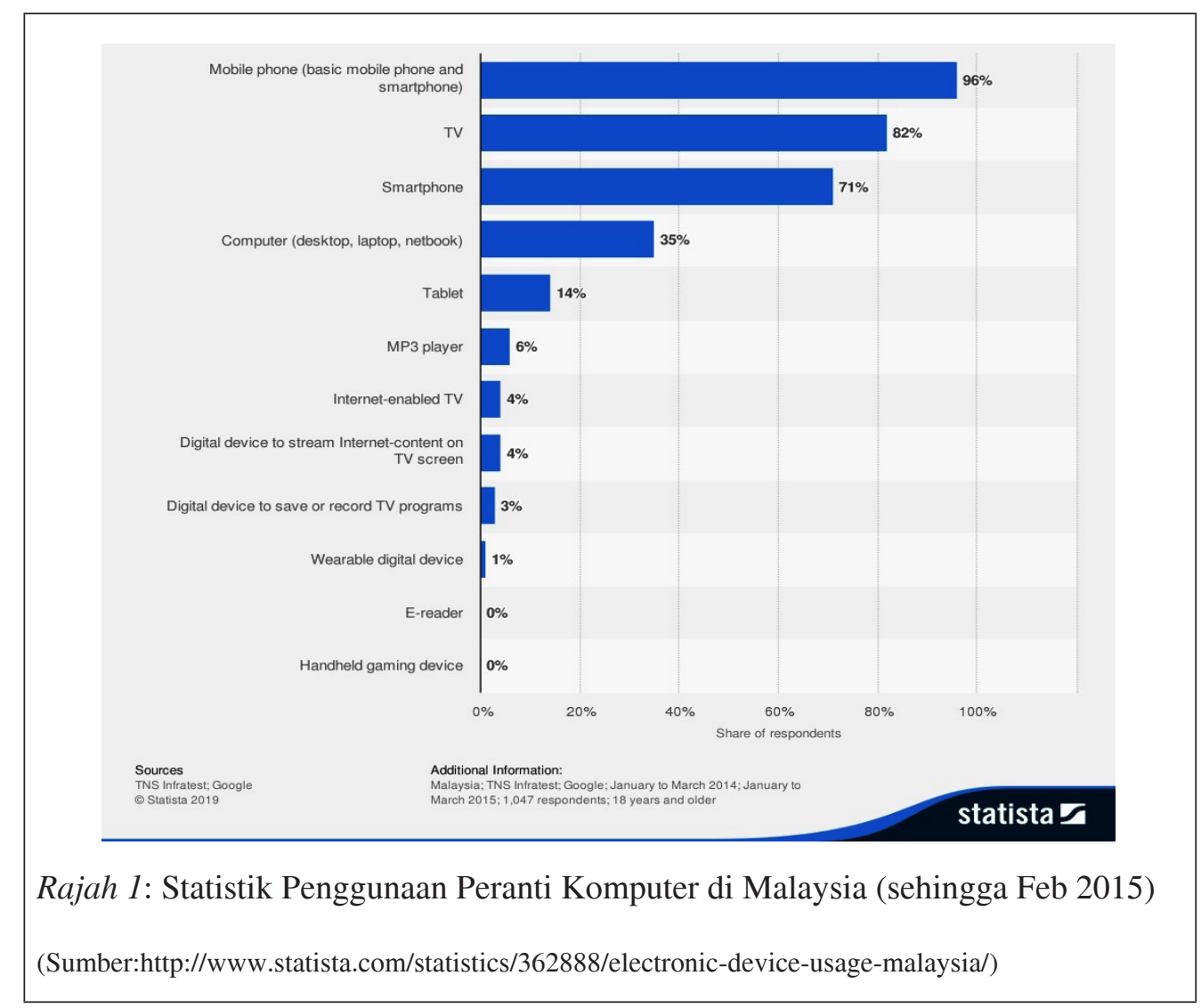


Statistik terkini yang dikeluarkan oleh Jabatan Statistik Malaysia pada tahun 2019 menunjukkan, peratusan penggunaan ICT dalam kalangan isi rumah meningkat dari tahun 2018 berbanding tahun 2017 (Rajah 2). Peningkatan juga dapat dilihat dalam penggunaan Internet, komputer dan telefon mudah alih dalam kalangan individu.

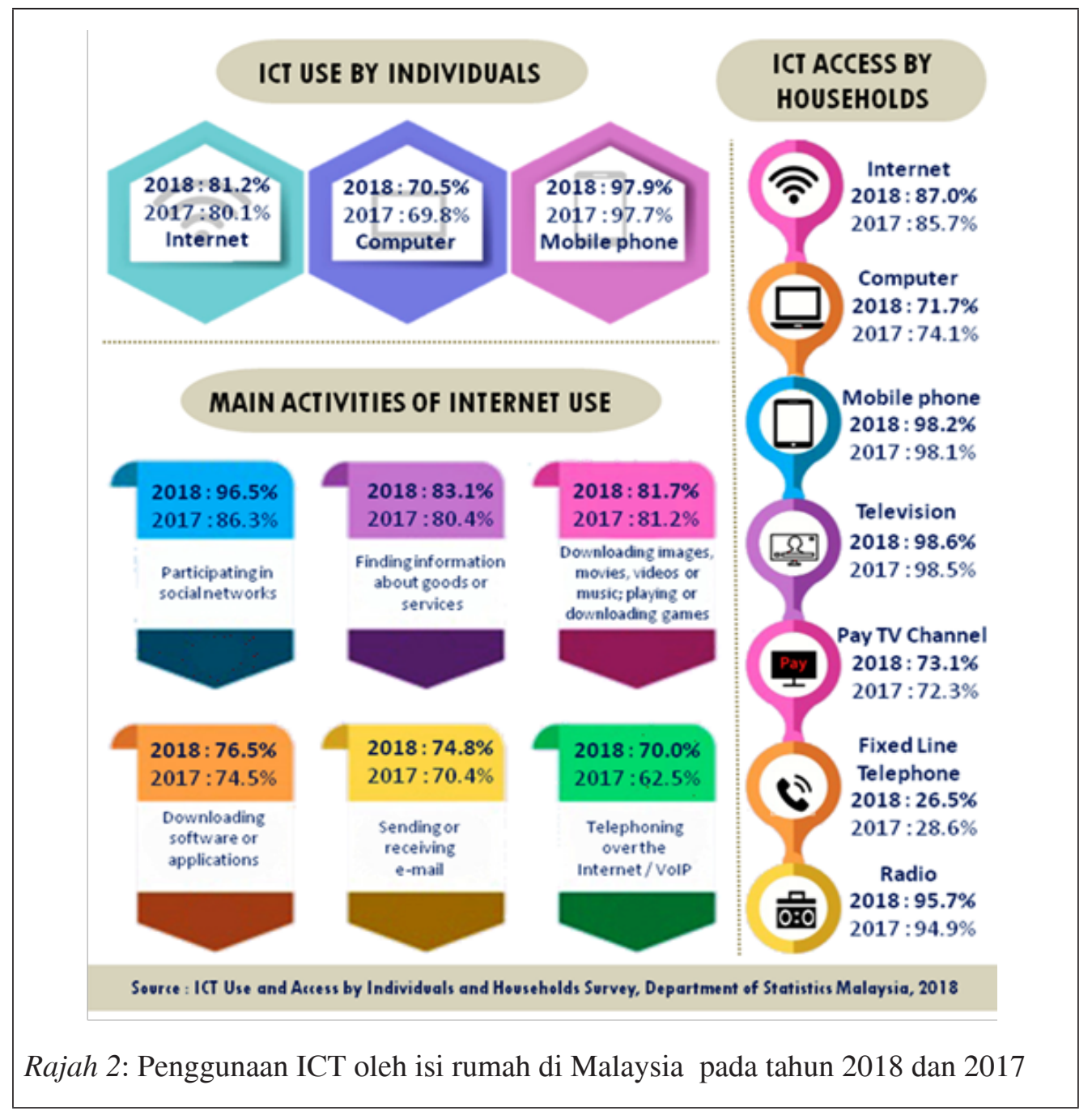

Merujuk laporan Internet Users Survey 2018 yang dijalankan oleh Suruhanjaya Komunikasi dan Multimedia Malaysia (SKMM), pengguna Internet di Malaysia telah meningkat dari 76.9\% (24.5 juta) dalam tahun 2016 kepada $87.4 \%$ (28.7 juta) dalam tahun 2018 (SKMM, 2018b). Kajian tersebut juga mendapati telefon pintar merupakan peranti yang lazim digunakan bagi mencapai Internet. Sementara itu, penggunaan peranti lain seperti smart TV, TV streaming box dan game console turut menunjukkan peningkatan. 
Selain isi rumah, Internet juga penting dalam pembangunan industri (Mui et al., 2002). Ini kerana, Internet membuka pasaran yang lebih luas kepada pemasaran produk, pengurusan dan membantu memudahkan komunikasi. Pelajar juga perlu menguasai Internet dengan betul. Ini kerana Internet merupakan salah satu teknologi ICT yang berkembang dengan pantas. Melalui Internet pelajar bukan sahaja boleh mendapat pelbagai manfaat tetapi juga keburukan seperti ketagihan dan salah guna Internet. Penggunaan Internet dengan betul boleh meningkatkan prestasi pelajar dan meningkatkan tahap e-kemahiran mereka.

Penggunaan ICT dalam industri juga boleh dilihat melalui status MSC Malaysia yang dianugerahkan oleh kerajaan melalui Malaysia Digital Economy Corporation Sdn Bhd (MDEC). Status ini melambangkan pengiktirafan kerajaan Malaysia terhadap amalan dan penggunaan teknologi ICT dalam pelbagai aspek operasi organisasi seperti pengurusan dan peningkatan pengeluaran produk dan perkhidmatan. Merujuk laman web MDEC (https://mdec.my/what-we-offer/msc-malaysia/), sehingga Mei 2019 terdapat 2,954 syarikat berstatus MSC yang aktif. Pada tahun 2018, syarikat-syarikat ini telah menjana pulangan hasil sebanyak RM 472 bilion dan sejumlah 182,538 pekerjaan telah diwujudkan.

Seperti yang telah dibincangkan di atas, perkembangan dan kemajuan ICT serta penggunaannya dalam kalangan masyarakat dan organisasi di Malaysia menunjukkan bahawa ICT merupakan antara alatan yang sangat penting dan cepat berkembang. Justeru, penguasaan ICT dalam kalangan pelajar amat penting. Ini kerana, pelajar merupakan golongan yang akan mengisi keperluan tenaga kerja dalam pelbagai sektor industri di Malaysia. Kemahiran ICT yang dikuasai mereka mampu membantu organisasi meningkatkan kecekapan pengurusan dan operasi.

\subsection{Kaedah Kajian}

Kajian ini melibatkan sekumpulan pelajar tahun akhir sebagai responden. Pelajar dipilih secara rawak dari tiga kolej pengajian di Universiti Utara Malaysia (UUM). Pelajar tahun akhir dipilih kerana golongan ini telah mengaplikasikan ICT dalam pembelajaran mereka samada secara langsung atau tidak, bakal menamatkan pengajian, dan bakal memasuki dunia pekerjaan. Pelajar diberi soal selidik yang diadaptasi dari Yusof dan Balogun (2011). Soal selidik ini bermatlamat untuk mengukur persepsi pelajar terhadap kepentingan ICT. Soal selidik ini terdiri daripada 12 soalan (Jadual 1) menggunakan skala likert 1 hingga 4. Skala ini mewakili sangat tidak setuju (1), tidak setuju (2), setuju (3), dan sangat setuju (4). 
Jadual 1

Soalan bagi Mengukur Persepsi Pelajar terhadap ICT

\begin{tabular}{ll}
\hline No. & Soalan \\
\hline 1. & ICT enhances my learning. \\
2. & ICT provides better learning experiences. \\
3. & I would work harder if I could use ICT. \\
4. & I learn more from ICT than I do from books. \\
5. & ICT is useful in dissemination of information. \\
6. & ICT makes the course more interesting. \\
7. & ICT skill is worthwhile. \\
8. & ICT gives opportunity to learn more. \\
9. & I won't have anything to do with ICT. \\
10. & I have a phobia for ICT equipment. \\
11. & ICT can't address the needs of the university system. \\
12. & The state of facilities discourages me from using ICT \\
\hline
\end{tabular}

Seterusnya kajian secara praktikal dijalankan di makmal komputer dan dipantau oleh seorang fasilitator. Pelajar diberikan satu tugasan iaitu menyediakan sepuluh sijil menggunakan perisian Microsoft Word. Tugasan ini bermatlamat untuk menilai tahap usaha pelajar menggunakan peralatan dan perisian ICT sewaktu menyiapkan tugasan yang diberikan. Pelajar digalakkan menggunakan perisian berkaitan dalam usaha menyiapkan tugasan berkenaan.

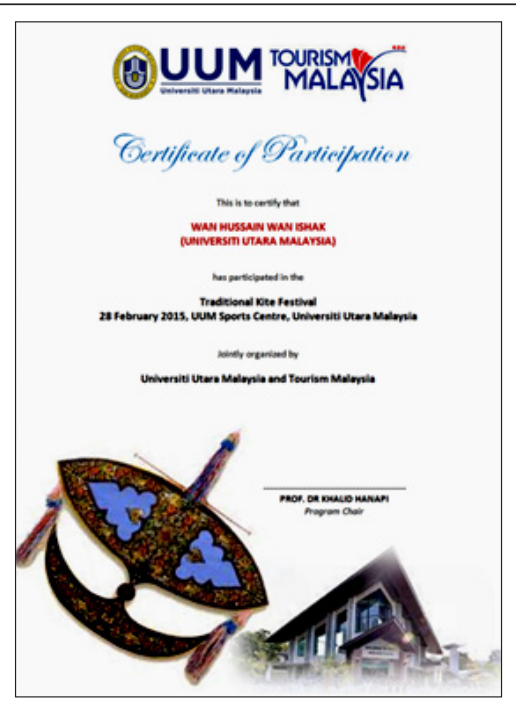

Rajah 3: Contoh Sijil 
Contoh sijil disediakan seperti dalam Rajah 3. Pelajar dikehendaki menyediakan sijil seperti contoh yang diberikan dalam masa satu jam sahaja. Pelajar juga dikehendaki mendapatkan gambar yang hampir sama seperti yang digunakan dalam sijil berkenaan di Internet. Gambar berkenaan perlu dimanipulasi (Rajah 4) dan disusun di atas sijil seperti contoh yang diberikan (Rajah 3).

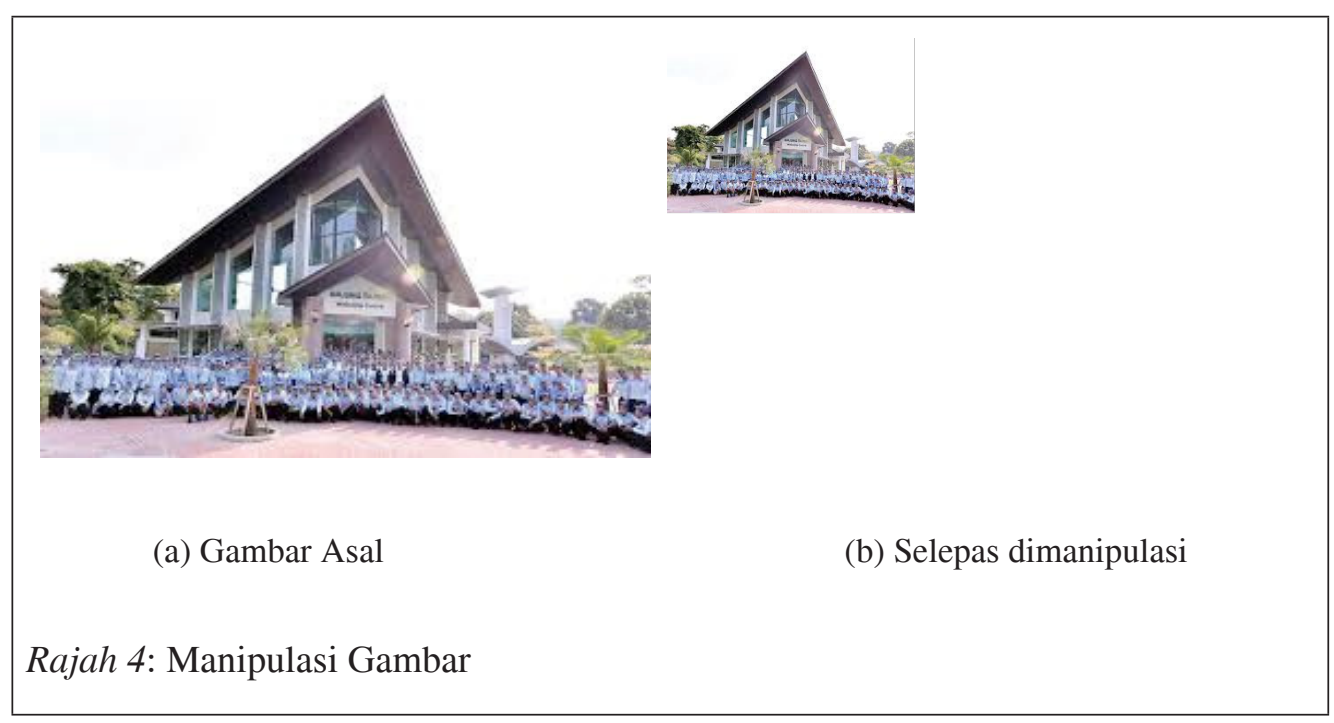

Setelah selesai tugasan, pelajar diarahkan supaya menghantar 10 sijil berkenaan berserta gambar asal yang mereka gunakan kepada fasilitator melalui e-mel. Hasil kerja pelajar akan disemak dan diberi markah dan gred seperti dalam Jadual 22.

Melalui ujian ini tahap sebenar penguasaan ICT dalam kalangan pelajar dapat nilai seperti berikut:

1) Menggunakan Microsoft Word dengan betul dan berkesan

2) Mendapatkan gambar bersesuaian dari sumber Internet menggunakan enjin carian Google

3) Menggunakan perisian bersesuaian bagi menyunting gambar

4) Menguruskan bahan-bahan dan fail berkaitan dalam komputer dengan efisien (seperti menyediakan folder dan sub-folder)

5) Menggunakan perisian zip atau rar untuk compress fail sebelum dihantar melalui e-mel.

6) Menggunakan e-mel dengan betul. 
Jadual 2

Julat Markah dan Gred

\begin{tabular}{cl}
\hline Julat Markah & Gred \\
\hline$x<34.45$ & $\mathrm{~F}$ \\
$34.45<=x<39.45$ & $\mathrm{D}$ \\
$39.45<=x<44.45$ & $\mathrm{D}+$ \\
$44.45<=x<49.45$ & $\mathrm{C}-$ \\
$49.45<=x<54.45$ & $\mathrm{C}$ \\
$54.45<=x<59.45$ & $\mathrm{C}+$ \\
$59.45<=x<64.45$ & $\mathrm{~B}-$ \\
$64.45<=x<69.45$ & $\mathrm{~B}$ \\
$69.45<=x<74.45$ & $\mathrm{~B}+$ \\
$74.45<=x<79.45$ & $\mathrm{~A}-$ \\
$79.45<=x<89.45$ & $\mathrm{~A}$ \\
$x>=89.45$ & $\mathrm{~A}+$ \\
\hline
\end{tabular}

\subsection{Dapatan Kajian dan Perbincangan}

Jumlah keseluruhan pelajar yang terlibat dalam kajian ini adalah 63 orang dan dibahagikan kepada dua kumpulan mengikut kapasiti makmal komputer yang digunakan. Rajah 5 menunjukkan taburan pelajar yang terlibat mengikut jantina. Seperti yang ditunjukkan dalam Rajah 5, kebanyakan responden adalah perempuan (83\%), manakala lelaki hanya $17 \%$ sahaja.

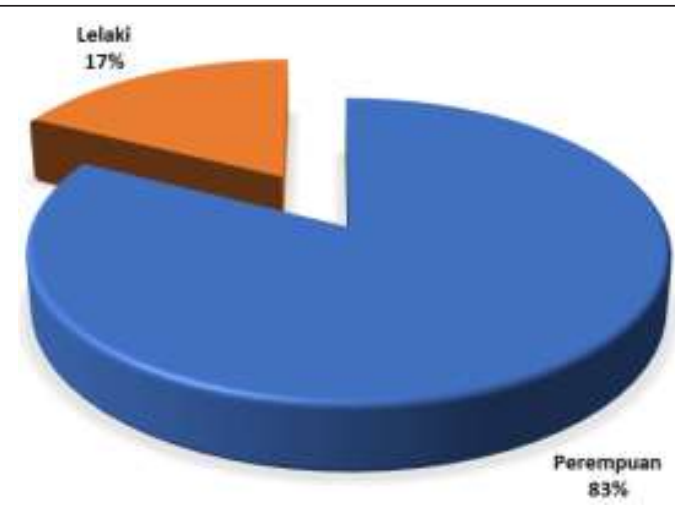

Rajah 5: Jantina 
Jadual 3 menunjukkan persepsi pelajar terhadap ICT. Maklum balas pelajar dipermudahkan perwakilannya dengan menggabungkan skala 1 hingga 4 kepada 2 kelas; setuju dan tidak setuju. Maklum balas dengan skala 1 dan 2 dikelaskan sebagai tidak setuju, manakala skala 3 dan 4 adalah setuju. Seperti yang ditunjukkan dalam Jadual 3, majoriti pelajar mempunyai persepsi yang positif terhadap ICT. Pelajar bersetuju bahawa ICT sangat bermanfaat untuk pengajian dan aktiviti harian mereka. Hasil kajian ini juga menunjukkan bahawa pelajar menyedari bahawa ICT sangat penting bagi kerjaya masa hadapan mereka.

Jadual 3

Persepsi Pelajar terhadap ICT

\begin{tabular}{llcc}
\hline Bil & Soalan & $\begin{array}{c}\text { Setuju } \\
(\boldsymbol{\%})\end{array}$ & $\begin{array}{c}\text { Tidak Setuju } \\
(\boldsymbol{\%})\end{array}$ \\
\hline 1. & ICT enhances my learning. & 100 & 0 \\
2. & ICT provides better learning experiences. & 100 & 0 \\
3. & I would work harder if I could use ICT. & 90.48 & 9.52 \\
4. & I learn more from ICT than I do from books. & 76.19 & 23.81 \\
5. & ICT is useful in dissemination of information. & 96.83 & 3.17 \\
6. & ICT makes the course more interesting. & 96.83 & 3.17 \\
7. & ICT skill is worthwhile. & 95.24 & 4.76 \\
8. & ICT gives opportunity to learn more. & 98.41 & 1.59 \\
9. & I won't have anything to do with ICT. & 9.52 & 90.48 \\
10. & I have a phobia for ICT equipment. & 7.94 & 92.06 \\
11. & ICT can't address the needs of the university system. & 17.46 & 82.54 \\
12. & The state of facilities discourages me from using ICT & 26.98 & 73.02 \\
\hline
\end{tabular}

Jadual 4 menunjukkan skor keseluruhan yang diperolehi oleh pelajar berdasarkan tugasan yang mereka telah selesaikan. Dua pelajar tidak menghantar tugasan, dua orang pelajar gagal tugasan tersebut, manakala pelajar yang lain lulus dengan gred minimum D+. Kebanyakan pelajar mendapat gred C, C+, B- dan B. Enam orang pelajar mendapat gred A dan tiga orang pelajar mendapat gred A-. Rajah 6 menunjukkan graf bagi taburan skor.

Jadual 5 pula menunjukkan skor kemahiran pelajar bagi setiap komponen dalam tugasan yang diberikan kepada mereka. Dapatan tersebut menunjukkan pelajar mempunyai kemahiran asas menggunakan Microsoft Word, menggunakan enjin carian, mencari dan memanipulasi gambar. Walau bagaimanapun pelajar didapati agak lemah membuat fungsi alignment dalam Microsoft Office. Pelajar juga didapati tidak menggunakan aplikasi mail-merge dalam tugasan ini kerana tidak menyedari bahawa 
fungsi mail-merge bukan sahaja boleh digunakan untuk penyediaan surat, tetapi juga dalam penyediaan sijil.

Jadual 4

Skor bagi Tugasan

\begin{tabular}{cccc}
\hline Skor Minimum & Gred & Kekerapan & Peratus \\
\hline & TIDAK HANTAR & 2 & 3.17 \\
34.45 & F & 2 & 3.17 \\
39.45 & D & 0 & 0.00 \\
44.45 & D + & 4 & 6.35 \\
49.45 & C- & 3 & 4.76 \\
54.45 & C & 9 & 14.29 \\
59.45 & C+ & 8 & 12.70 \\
64.45 & B- & 10 & 15.87 \\
69.45 & B & 11 & 17.46 \\
74.45 & B + & 5 & 7.94 \\
79.45 & A- & 3 & 4.76 \\
89.45 & A & 6 & 9.52 \\
& A+ & 0 & 0.00 \\
& JUMLAH & $\mathbf{6 3}$ & $\mathbf{1 0 0}$ \\
\hline
\end{tabular}

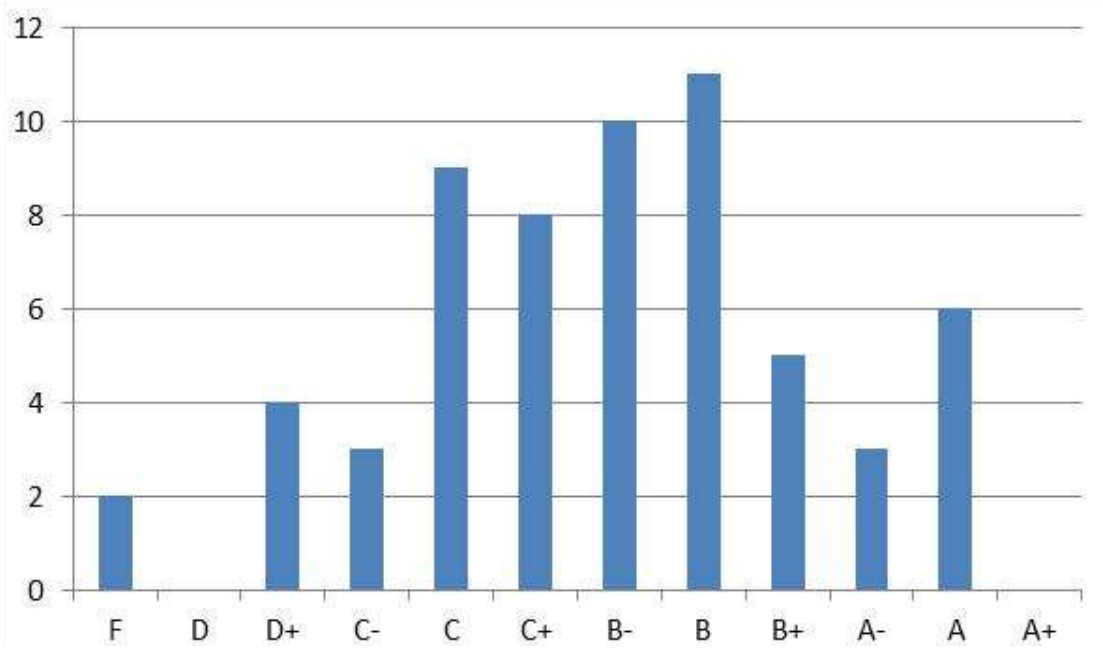

Rajah 6: Graf Taburan Skor 
Jadual 5

Skor Kemahiran Pelajar mengikut Aktiviti

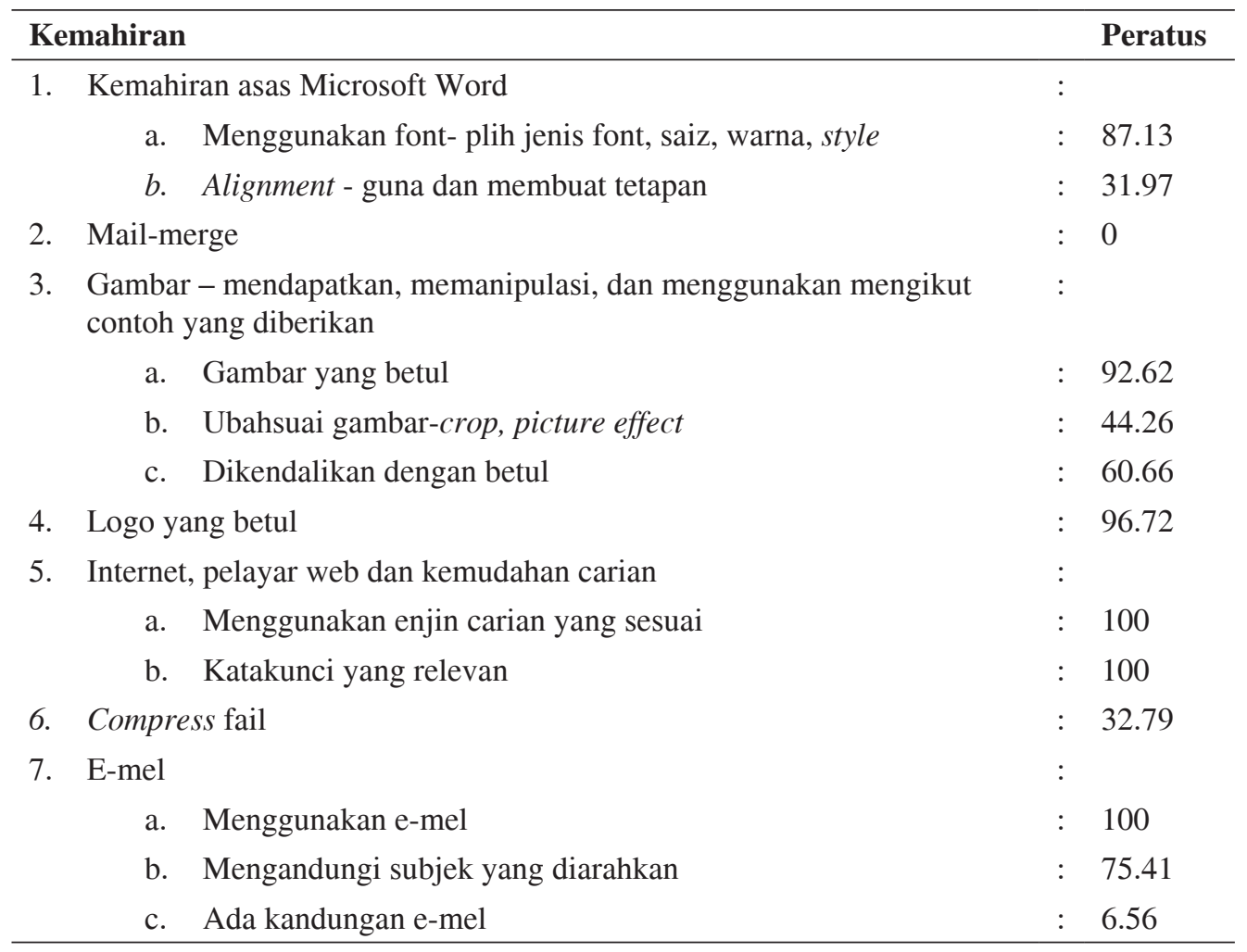

Kebanyakan pelajar juga tidak menggunakan perisian untuk compress fail. Hanya $32.79 \%$ sahaja yang menghantar lampiran tugasan yang telah dicompress (contoh Rajah 9). Dari aspek penggunaan e-mel, kesemua pelajar telah menghantar tugasan menggunakan e-mel. Ini menunjukkan mereka mempunyai pengetahuan asas menggunakan e-mel. Walaubagaimanapun, tidak ramai pelajar menggunakan e-mel dengan betul seperti meletakkan subjek yang bersesuaian dan menulis kandungan e-mel (Rajah 7). Malah ramai pelajar yang hanya menghantar e-mel hanya dengan lampiran tanpa sebarang tulisan di bahagian kandungan e-mel (Rajah 8, Rajah 9 dan Rajah 10).

Jadual 6 menunjukkan senarai perisian yang digunakan oleh pelajar. Dalam menyiapkan tugasan ini pelajar didapati telah menggunakan pelbagai perisian sampingan seperti Adobe Photoshop, Microsoft Excel, Microsoft Publisher, Microsoft PowerPoint, paint dan sebagainya. 
Jadual 6

Senarai Perisian yag digunakan oleh pelajar

\begin{tabular}{ll}
\hline Perisian & Kegunaan \\
\hline 1. Microsoft Word & Menghasilkan sijil \\
2. Adobe Photoshop & Mengubahsuai gambar \\
3. Adobe Reader & PDF \\
4. Microsoft Excel & Menyediakan senarai peserta (data bagi sijil) \\
5. Microsoft Publisher & Dekorasi/templat sijil \\
6. Microsoft Powerpoint & Menyunting gambar \\
7. Nero & Menyunting gambar \\
8. Paint & Menyunting gambar \\
9. Win RAR & Compress fail \\
10. Zip & Compress fail \\
\hline
\end{tabular}

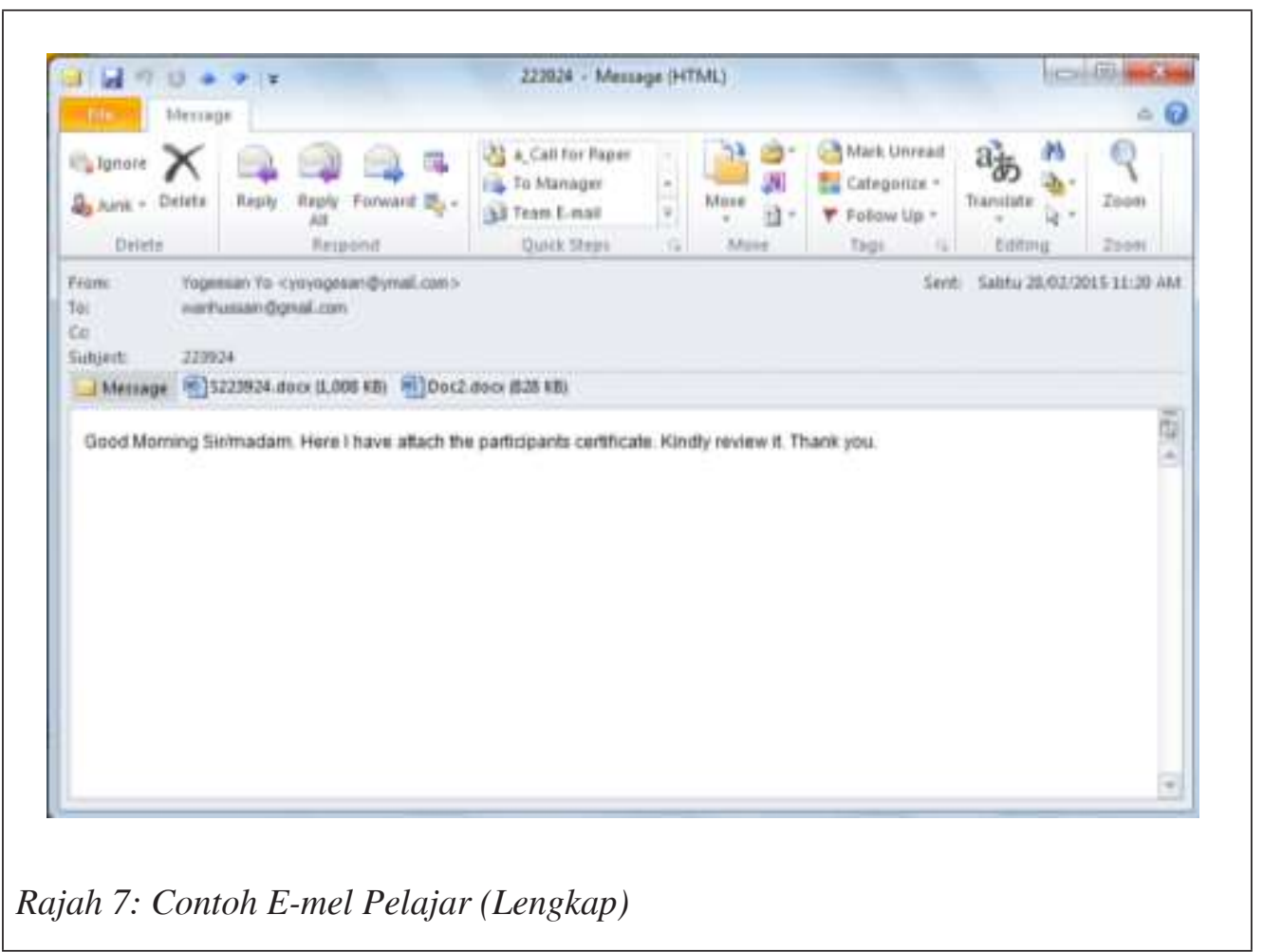




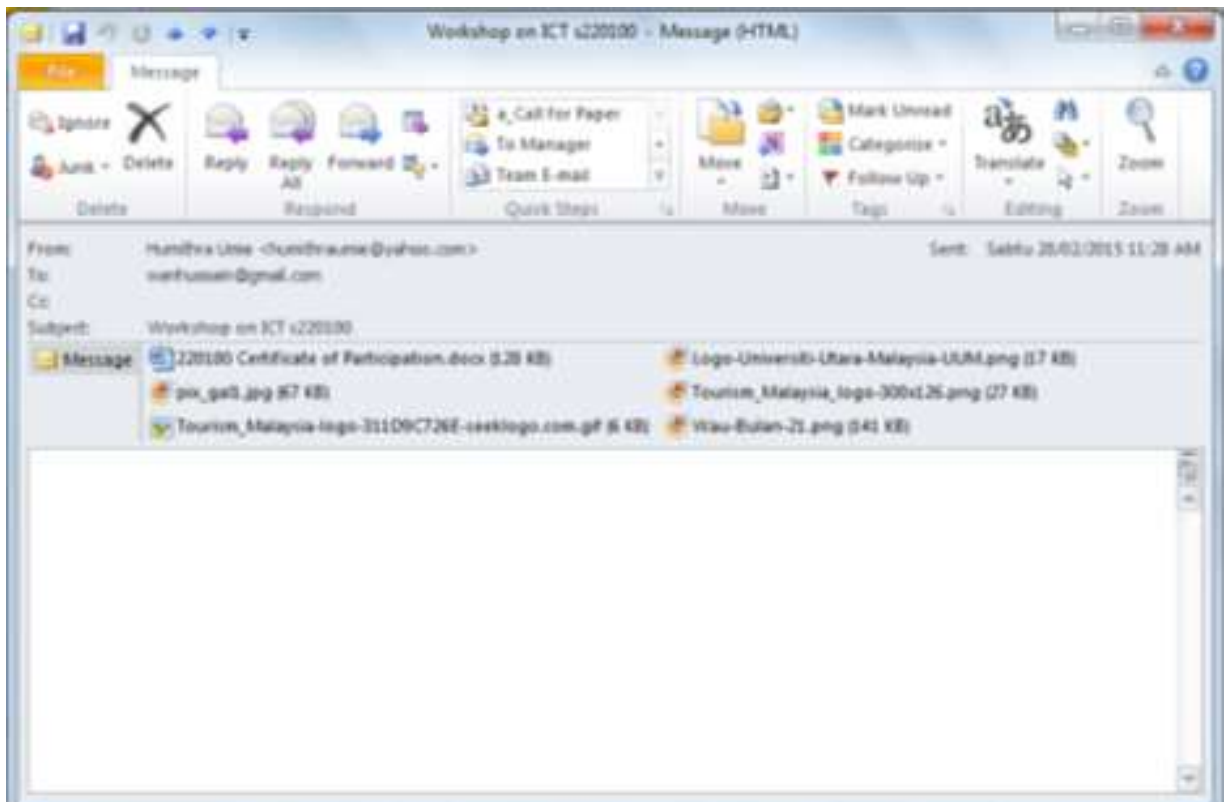

Rajah 8: Contoh E-mel Pelajar 1 (Lampiran Uncompress)

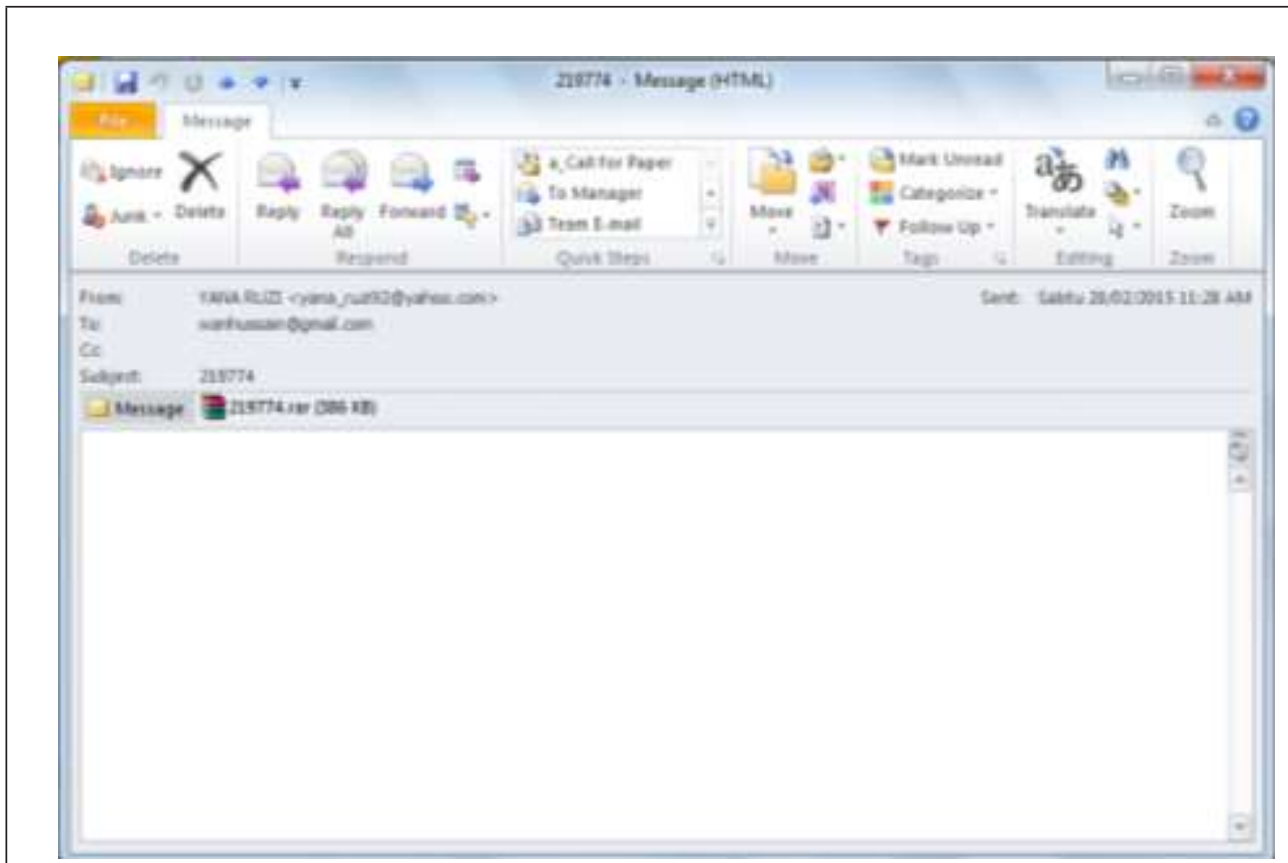

Rajah 9: Contoh E-mel Pelajar 2 (lampiran Compress) 


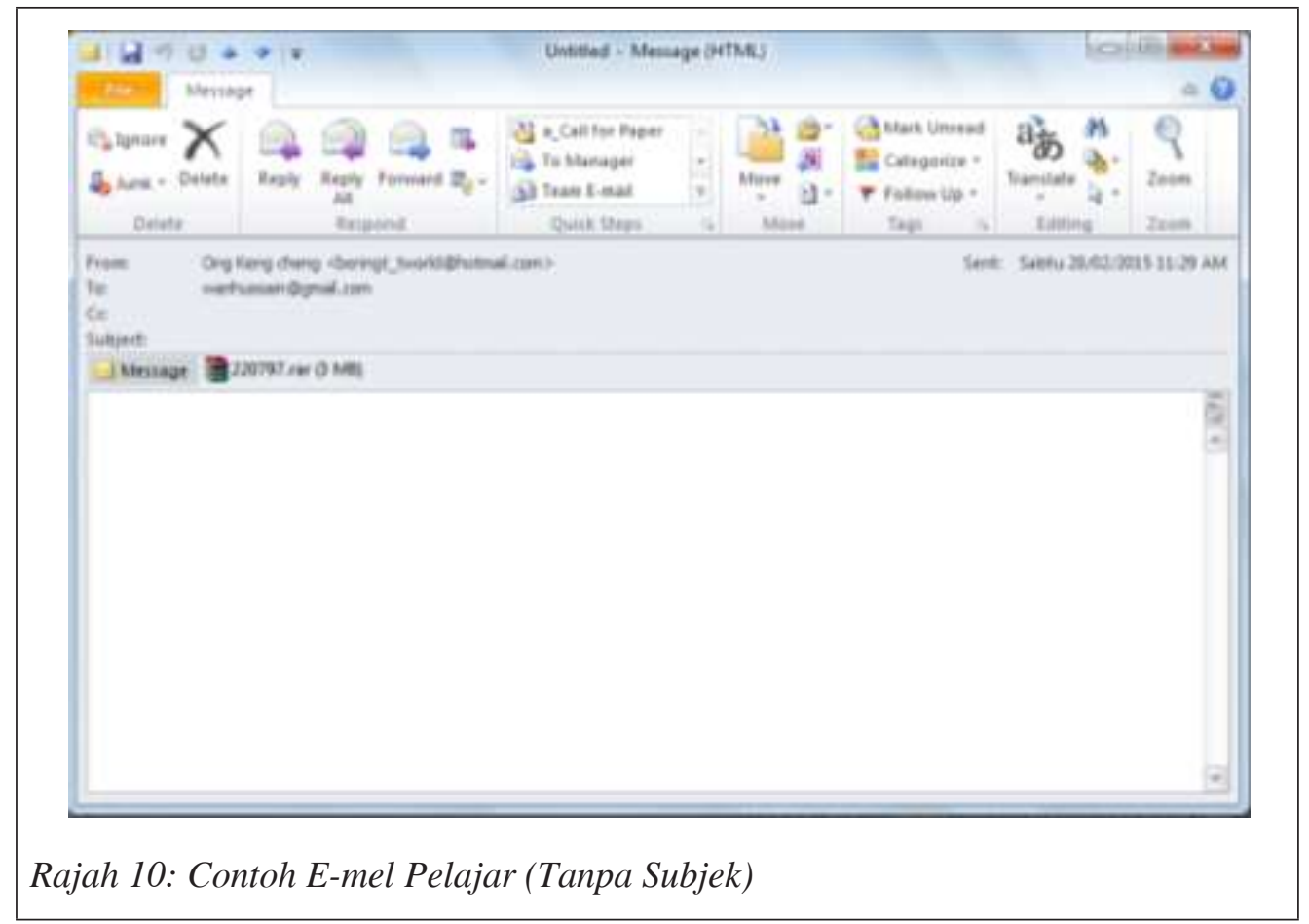

\subsection{Kesimpulan}

Secara keseluruhannya, kajian mendapati pelajar di UUM telah didedahkan dengan pelbagai teknologi ICT dan aplikasi komputer. Teknologi dan aplikasi ini sering diaplikasikan dalam proses pembelajaran pelajar (Yamin \& Ishak, 2017). Implementasi seperti ini secara tidak langsung membentuk kemahiran ICT dalam kalangan pelajar. Malah dapatan kajian juga menunjukkan bahawa pelajar amat maklum akan kepentingan ICT dalam pembelajaran dan kerjaya mereka.

Walau bagaimanapun, dapatan daripada tugasan yang telah dilaksanakan menunjukkan penguasaan sebenar pelajar iaitu keupayaan praktikal masih di tahap sederhana. Majoriti pelajar didapati berada dalam skala gred $\mathrm{C}$ hingga $\mathrm{B}$. Manakala peratusan pelajar yang mendapat gred A amat rendah berbanding keseluruhan pelajar. Kewujudan pelajar yang gagal juga amat membimbangkan. Dapatan kajian ini perlu diberi perhatian kerana pelajar yang telah melalui proses P\&P secara e-pembelajaran sewajarnya mempunyai kemahiran ICT yang baik seperti yang diutarakan oleh An et al (2009). Oleh itu, pelajar perlu meningkatkan usaha untuk belajar dan meningkatkan kemahiran ICT mereka. Revolusi industri 4.0 atau IR4.0 memerlukan tenaga kerja yang bukan sahaja "tahu" teknologi tetapi juga mampu mengamalkan dan menggunakan teknologi berkenaan dalam penyelesaian masalah di organisasi. 
Kemahiran ICT perlu dipertingkatkan sebelum pelajar menamatkan pengajian bagi menyediakan diri mereka untuk persekitaran kerja sebenar. Pada masa yang sama, pensyarah perlu mengambil inisiatif menggalakkan pelajar menggunakan pengetahuan dan kemahiran ICT dalam proses pembelajaran mereka. Pihak universiti juga perlu merangka kaedah yang bersesuaian bagi mendedahkan pelajar dengan teknologi ICT terkini. Pendekatan amalan ICT secara terbenam dalam kurikulum sedia ada perlu dipertingkatkan. Ini bagi membolehkan pelajar mendapat pendedahan dan mengamalkan teknologi terkini dalam proses pembelajaran mereka.

Pelajar juga perlu sentiasa kemaskini pengetahuan mereka dengan isu terkini dalam bidang ICT. Maklumat ini akan membantu pelajar lebih bersedia dan mencari ruang untuk mendalami ilmu ICT berkaitan.

\section{Penghargaan}

Kajian ini dijalankan di bawah pembiayaan Skim Geran Pembangunan Pelajar, Universiti Utara Malaysia (Kod S/O: 13088).

\section{Rujukan}

An, Y-J., Aworuwa, B., Ballard, G., \& Williams, K. (2009). Teaching with Web 2.0 Technologies: Benefits, Barriers and Best Practices. Proceedings of the Annual Convention of the AECT, pp. 1-6.

Basri, W.S., Alandejani, J.A, \& Almadani, F.M. (2018). ICT Adoption Impact on Students' Academic Performance: Evidence from Saudi Universities. Education Research International, Vol. 2018, Article ID 1240197, 9 pages, 2018. https:// doi.org/10.1155/2018/1240197.

Department of Statistics Malaysia (2019). ICT Use and Access by Individuals and Households Survey Report Malaysia 2018. Dicapai dari https://www.dosm.gov.my/

Gareis, K., Husing, T., Birov, S., Bludova, I., Schulz, C., \& Korte, W.B. (2014). E-Skills for Jobs in Europe: Measuring Progress and Moving Ahead. Technical Report. European Commission.

Hernandez, R.M. (2017). Impact of ICT on Education: Challenges and Perspectives. Propósitosy Representaciones, 5(1), 325-347.

Hoskins \& Van Hooff (2005). Motivation and Ability: Which Students Use Online Learning and What Influence does it have on their Achievement? British Journal of Educational Technology, 36(2), 17-192.

Ishak, W.H.W., Yamin, F.M. \& Ibrahim, A. (2015). Teknologi Web 2.0 dalam Menyokong Pembelajaran dan Pengajaran, Prosiding Seminar Kebangsaan Transformasi Sosio-Ekonomi NCER Kali Ke-2, Sungai Petani, Kedah, 25-26 Februari 2015, pp. 312-323. 
Lanvin, B., \& Kralik, M. (2009). E-Skills: Who Made That Big Dent in My Flat World? Information Technologies and International Development, 5(2), 81-84.

Linton, I. (2018). The Benefits of Using ICTs in Business \& Finance. Retrieved on February 25, 2019 from https://bizfluent.com/list-6641121-benefits-using-ictsbusiness-finance.html

MDEC (2016). MSC Malaysia Annual Industry Report 2015. Malaysia Digital Economy Corporation Sdn. Bhd.: Malaysia.

MITI (2018). Industry 4WRD: National Policy on Industry 4.0. Ministry of International Trade and Industry: Malaysia

Mui, L.Y., Aziz, A.R.A., Ni, A.C., Yee, W.C. \& Lay, W.S (2002). A Survey of Internet Usage in the Malaysian Construction Industry. Journal of Information Technology in Construction, 7, 259-269.

Palvalin, M., Lönnqvist, A., \& Vuolle, M. (2013). Analysing the impacts of ICT on knowledge work productivity. Journal of Knowledge Management, 17(4), 545557.

Plaatjies. F., \& Mitrovic, Z. (2014). ICT and Skills Shortage: South African Case Study of Retaining ICT-Skilled Professionals. Proceedings of the e-Skills for Knowledge Production and Innovation Conference, Cape Town, South Africa, pp. 351-369.

Ramlan, J. \& Ahmed, E.M. (2010). The Impact of ICT in Malaysia: A Simultaneous Equations Approach. World Journal of Science, Technology and Sustainable Development, 7(1), 61-72.

SKMM (2018a). Komunikasi dan Multimedia: Buku Maklumat Statistik 2018. Suruhanjaya Komunikasi dan Multimedia Malaysia: Malaysia.

SKMM (2018b). Internet Users Survey 2018: Statistical Brief 23. Suruhanjaya Komunikasi dan Multimedia Malaysia: Malaysia

Toader, E., Firtescu, B.N., Roman, A. \& Anton, S.G. (2018). Impact of Information and Communication Technology Infrastructure on Economic Growth: An Empirical Assessment for the EU Countries. Sustainability, 10, 3750.

Tyler, L. (2005). ICT Literacy: Equipping Students to Succeed in an Information-Rich, Technology-Based Society. An Issue Paper. Educational Testing Service.

Yamin, F.M. \& Ishak, W.H.W. (2016) E-Skills of Undergraduate Students. Journal of Education and Social Sciences, 4(June), pp. 314-318.

Yamin, F.M. \& Ishak, W.H.W. (2017): Does the Blended Learning and Student Centered Learning Method Increase Student's Performance? Proceedings of the 1st Inspirational Scholar Symposium (ISS 2016), EDC UUM, Kedah, pp. 8-17. 